\title{
RELATO DE UNA JORNADA EN EL HOSPITAL
}

\author{
ARACELI Banyuls
}

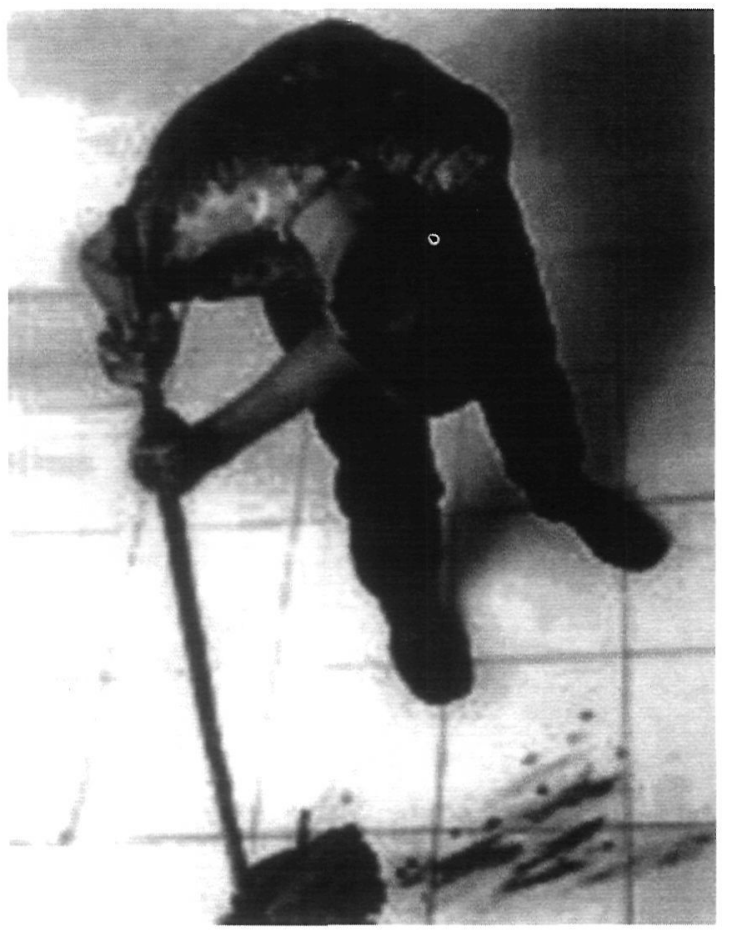

$\mathrm{C}$ uando entré a las ocho de la mañana a trabajar en el servicio de Urgencias, me tocó «camas» donde están los pacientes en espera de ser ingresados, o si mejoran marcharse a casa.

Me dieron el relevo matizando «En el cinco hay una insoportable», llegué a mi servicio y al entrar oí una voz que cantaba: «DÓNDE ESTARÁ MI CARRO...». Yo intenté poner una nota de humor y dije: Anda de buena mañana y buscando el carro.

Antes de acercarme al número cinco, leí en su historia el nombre de ANTONIA HEREDIA. Me vino a la memoria su cara, su imagen, pues ya la conocía: 21 años VIH, un hijo de tres años y una vida por descubrir que jamás descubrirá.
Su cuerpo lapidado por todos los males que se puedan coger, se rebelaba gritando, arrancándose el gotero y pidiendo su dosis de metadona.

Sólo acerté a poner mi mano sobre su hombro y decirle unas palabras tiernamente.

Se calmó un poco, abrió sus ojos azules y me miró, intenté buscar un sentido, un por qué. Antonia era una víctima más de las muchas que pasan por los servicios de Urgencias. Antonia seguía gritando y la impotencia hervía en mis venas.

Por fin se hizo el ingreso, cuando los celadores se la llevaban, rocé con mis manos sus pies y dije: Adiós Antonia que seas buena.

Más cosas pasaron esa mañana, pero a Antonia le quedan pocas mañanas. Tal vez su destino sea ese, el de avisarnos con sus 21 años y su hijo de tres años.

Todos los profesionales de la Sanidad, aunque con voluntad de ayudar a nuestros pacientes hay momentos en los que llamamos insoportables a personas como Antonia y a veces sólo con cogerles la mano y escuchar en silencio lo que dicen, tal vez les podríamos animar un poco más.

No siempre se tiene tiempo para ello pero cuando lo tenemos, va bien practicarlo, después de pincharle el gotero.

Porque la técnica es importante, pero sin una actitud humana. Es como un cubo sin cuerda, no se puede llegar al agua, qué sería esa conexión entre paciente y enfermera o dicho de una forma más científica, sería una relación de Empatía.

\section{ANTON1A ESTARÁ ESTA NOCHE EN SU HABITACIÓN.}

EN EL SERVICIO DE MEDICINA INTERNA DEL HOSPITAL, ARROPADA POR SUS DOLORES, PIDIENDO SU PASTILLA PARA DORMIR...

DORMIR... DURMIENDO SE OLVIDA DE QUE SU CUERPO, APENAS TIRA. 